\title{
ATTEMPTS AT THERMOLUMINESCENCE DATING OF FIRED MATERIALS FROM THE PRZEWORSK CULTURE SETTLEMENTS
}

\author{
JAROSLAW KUSIAK ${ }^{1}$, MARIUSZ RYCHTER ${ }^{2}$ and MARTA STASIAK-CYRAN ${ }^{\mathbf{3}}$ \\ ${ }^{I}$ Department of Physical Geography and Palaeogeography, Maria Curie-Skłodowska University, \\ Al. Kraśnicka 2 cd, 20-718 Lublin, Poland \\ ${ }^{2}$ Institute of Archaeology, University of Łódź, Jaracza 78, 90-243 Łódź, Poland \\ ${ }^{3}$ The Lublin Province Museum, Zamkowa 9, 20-117 Lublin, Poland
}

Received 13 May $2010 \quad$ Accepted 25 March 2011

\begin{abstract}
The thermoluminescence (TL) dating method has a significant measurement error margin reaching almost $10 \%$. Due to this fact it could be considered as little effective in case of such sites from the Roman period as burial grounds with many artefacts useful for archaeological dating. However, for many settlements from this period, where pottery is the only kind of artefacts, the TL method can give notable results. The main purpose of the study was to make an attempt at TL dating of pottery and clay daub samples from the Nieszawa Kolonia and Kręcieszki sites and to compare the obtained dates with the results of archaeological dating of selected features from the Przeworsk Culture settlements. In the Kręcieszki site the fragments of burnt clay daub were dated by the TL method for the first time in the Lublin laboratory. It turned out that clay daub is an equally good dating material as pottery. It can be found that the TL dating of pottery from Nieszawa Kolonia confirms two stages of settlement. The first settlement stage is related to the phases B2-B2/C1-C1a of the Roman period, i.e. from the beginning of the $2^{\text {nd }}$ to the beginning of the $3^{\text {rd }}$ century. The second group of TL dates corresponds to the phases C2D that is to the second stage of settlement, from the second half of the $3^{\text {rd }}$ century to the half of the $5^{\text {th }}$ century AD. The results of TL dating of pottery and clay daub in the Kręcieszki site are rather similar and correspond to the phase B1/B2 of the period of Roman influence, determined from pottery style, but can also indicate the phase $\mathrm{B} 2 / \mathrm{C} 1$.
\end{abstract}

Keywords: TL dating, pottery, clay daub, Roman period, Migration period, Przeworsk Culture.

\section{INTRODUCTION}

The Nieszawa Kolonia village (Opole county, Lublin province) is situated in the Małopolska Vistula River Gap belonging to the Lublin Upland (Fig. 1) (Kondracki, 1994).

The Przeworsk Culture settlement occurring in this village is the best examined settlement site from the older Roman period in the Lublin region, and the second after the Drążgów site, which provides information about

Corresponding author: J. Kusiak

e-mail: jaroslaw.kusiak@umcs.lublin.pl dwelling construction of the Przeworsk Culture population (Kokowski, 1989; Stasiak-Cyran, 2000). Its total area can reach even 1 ha though only $2215.8 \mathrm{~m}^{2}$ has been discovered to date (Stasiak-Cyran, 2005; 2008). Twelve dwelling features were described in this site to date (Fig. 2).

The settlement in Nieszawa Kolonia, the site No. 5, does not differ from the settlement schemes found in the other areas of the Przeworsk Culture (cf. Michałowski, 2003), both in respect of its situation and pattern. It is situated on a small promontory rising over the floodplain of the Wyżnica River near its mouth to the Vistula River (Fig. 1). The arrangement of features is random, without 


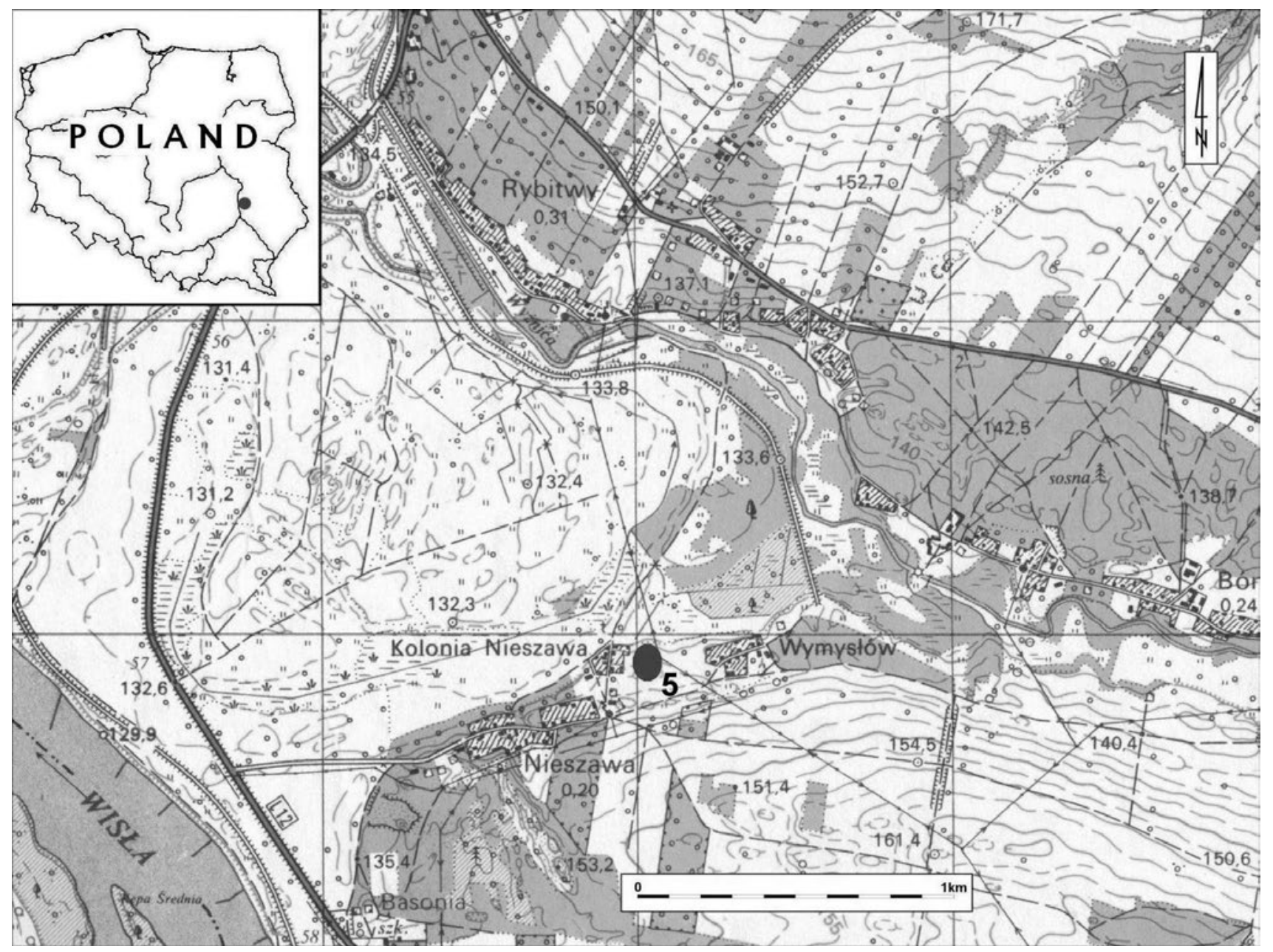

Fig. 1. Location of the Nieszawa Kolonia site

division into dwelling and production zones. It is rather a farmstead type of spatial arrangement, with dwelling structures accompanied by domestic pits of different functions and hearths. The buildings regarded as dwellings have post construction only. The floor area of "houses" is from a dozen or so to over $50 \mathrm{~m}^{2}$. They are differently oriented to the directions of the world. They are sunk into the ground from 20 to $90 \mathrm{~cm}$, which indicates the overground or semi-subterranean character of buildings (Abramek, 1993; Stasiak-Cyran, 2005).

Most artefacts and features found in the Nieszawa Kolonia date from the phases $\mathrm{B} 2 \mathrm{~b}-\mathrm{B} 2 / \mathrm{C} 1-\mathrm{C} 1 \mathrm{a}$, i.e. from the period of development peak of the Przeworsk Culture settlement and then its collapse because of the expansion of the Wielbark Culture population in the Lublin region (Kokowski, 1991). However, besides these materials, among the pottery fragments occurring in the fillings of pits there are the fragments of Late Roman wheel-made pottery, which have been found in the Lublin region only in the sites of the Wielbark Culture and Masłomęcz Group (cf. Kokowski, 1988). The fragments of big stor- age vessels (so-called Krausengefässe) and metal artefacts such as bronze fibulae of VI Almgren group (late variant of A.158 brooch, two A.162 specimens and one A.166/167 specimen) seem to be exceptional findings (Stasiak-Cyran, 2000; 2005; 2008). In Silesia such storage vessels are related to the phases C3-D1 (Mączyńska, 1999). They are also known from many settlement sites from the Late Roman period in south-eastern Poland (Barłowska, 1984). Bronze fibulae are often found in the Przeworsk Culture sites from the younger Roman period (Szydłowski, 1964; Godłowski, 1981; Mączyńska, 1999).

The investigations carried out at the Nieszawa Kolonia site shed new light on the problem of the decline of the Przeworsk Culture settlement in south-eastern Poland. The occurrence of findings, dating probably from the phases C3-D1 of the Roman period, confirms that it is possible, as it has been signalled in literature (Kokowski, 1991), to discover features of the Przeworsk Culture somewhat younger than those discovered earlier. Therefore, the site was most probably settled again in the decline phase of this culture. According to the former state 


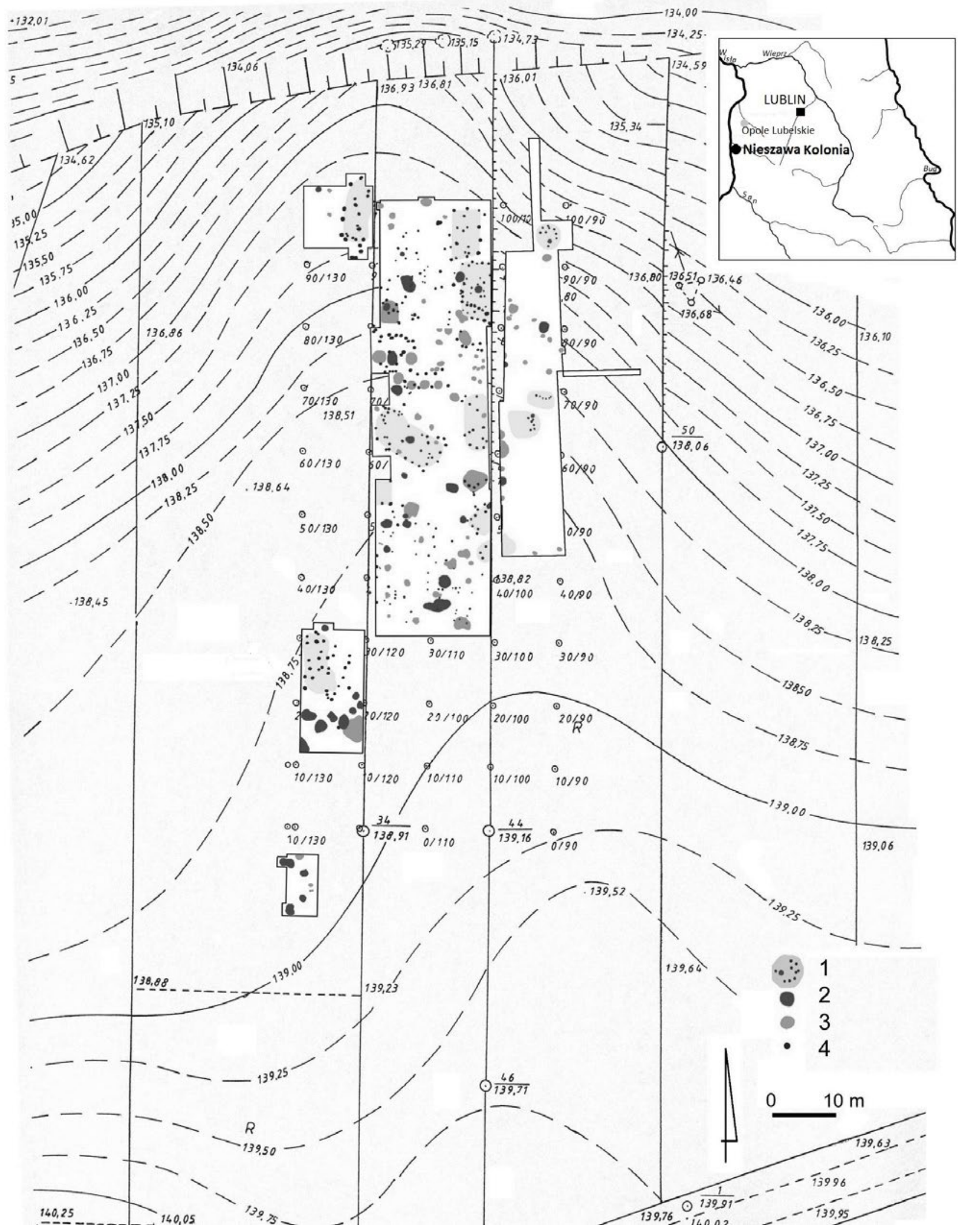

Fig. 2. Nieszawa Kolonia, site No. 5. Plan of the settlement; 1 - overground or semi-subterranean features of post construction, 2 - hearths and kilns, 3 - pits, 4 - post holes. 
of knowledge, the settlements of the Przeworsk Culture did not occur to the north-east of the San River in that time (Mączyńska, 1999). The discoveries in the site No. 5 in Nieszawa Kolonia make undoubtedly a breakthrough in the knowledge of settlement in the Lublin region in the Roman period (Stasiak-Cyran, 2000).

In 2008, based on archaeological materials obtained during the exploration, an attempt was made at TL dating of the site No. 5 in Nieszawa Kolonia. These analyses were a part of the project entitled: "Rescue investigations of the Przeworsk Culture settlement in Nieszawa Kolonia, Opole Lubelskie county: research with the use of non-invasive methods, specialist analyses, protection of the most endangered parts of the site from destruction". ${ }^{1}$

The main purpose of the study was to make an attempt at TL dating of pottery and clay daub ${ }^{2}$ samples and to compare the obtained dates with the results of archaeological dating of selected features. The next objective was to confirm the two stages of settlement: the first one during the phases $\mathrm{B} 2$ to $\mathrm{B} 2 / \mathrm{C} 1-\mathrm{C} 1 \mathrm{a}$, and the second one from the phase $\mathrm{C} 2$ or most probably $\mathrm{C} 3$ perhaps to the end of the phase D1 (?) as indicated by relative chronology determined from, among others, fragments of storage vessels (so-called Krausengefässe) and some metal artefacts (among others Stasiak-Cyran, 2000; 2008).

The site No. 1 in Kręcieszki was discovered in 1985 by the local farmer in Bedlno district (Kutno county, Łódź province), near the road A2 to Warsaw on low sandy elevation (Fig. 3). The site is situated on the Kutno Plain belonging to the Central Mazovian Lowland (Kondracki, 1994).

The excavations in the site No. 1 were conducted in five field seasons in the years 1987-1988 and 2005-2007. The site, at first considered as the monocultural burial ground of the Pomeranian Culture population with cist graves dated to the Hallstatt D and early La Tène periods, turned out to be the multicultural site.

The investigations revealed three settlement stages in this site. The first stage was connected with the Lusatian Culture (Rychter, 2010). The following units belonging to the settlement of the Lusatian population were found: storage pits, hearths, and probably remains of dwelling buildings (Rychter, 2010). Numerous fragments of pottery and flint material were dated to the IV/V period of the Bronze Age.

\footnotetext{
${ }^{1}$ The project was financed by the Ministry of Culture and National Heritage and The Lublin Province Museum.

${ }^{2}$ Daub: clay which is smeared onto a structure of timber or wattle (interwoven twigs) as a finish to the surface. It is normally added to both faces of a wall and is used to keep out drafts and give a smooth finish. The material usually survives only when baked or fire-hardened, as would be the case if a structure burned down. It can usually be recognized by the impressions of the wattle to be found on its inner face (Kipfer, 2007).
}

Then the area was settled by the Pomeranian Culture population (Rychter and Stasiak, 2006). Three cist graves discovered in the 1980s, and three urn burials beneath larger inverted urns found in 2007 were related to this culture.

The last settlement stage was that of the Przeworsk Culture population. The following traces of the Przeworsk Culture were found during the excavations conducted in 2005: one fragment of clay daub, loom-weight, and few fragments of pottery preliminary dated to the phase B1/B2 of the Roman period. The next remains of the settlement were found in the years 2006-2007. The part of dwelling feature discovered in 2006 measured four by two metres. It was very compact, burnt layer of clay daub about $20 \mathrm{~cm}$ thick. In the field season 2007 the second part of this feature was found, i.e. its southeastern corner. This relic measured 2.1 by 0.7 metres and was composed of two clay daub layers with the total thickness of about $25 \mathrm{~cm}$. Thus, this big building measured approximately 4.7 by 4.1 metres. None post holes were found so perhaps frame construction was used in buildings in this site.

The relic, probably of a small cellar with a diameter of about $50 \mathrm{~cm}$ and depth of $30 \mathrm{~cm}$, was found under the north-western corner of the house. It was strongly burnt clay daub with the fragments of pottery and lime. The pottery and clay daub were selected for TL dating.

\section{DESCRIPTION OF DATING METHOD}

In the case of pottery or clay daub, the TL dating determines the time which has passed since it was burnt. The TL age is a quotient of archaeological dose (AD) and dose rate (DR). The archaeological dose is a sum of the equivalent dose (ED) and correction (I) due to the fact of non-linear increase of thermoluminescence for small absorbed doses (Mejdahl and Wintle, 1984).

The determination of TL age of pottery and clay daub proceeds as follows. The dose rate is calculated from the measured concentrations of natural radioisotopes in a sample of pottery and sample of deposit in which it was found. The concentrations of radioisotopes obtained in $\mathrm{Bq} / \mathrm{kg}$ are converted into absorbed dose rates for $\alpha, \beta$ and $\gamma$ radiation in $\mathrm{Gy} / \mathrm{ka}$, based on the data published by Adamiec and Aitken (1998). In the calculation of DR the correction $\left(\mathrm{DR}_{\mathrm{c}}=0.15 \mathrm{~Gy} / \mathrm{ka}\right)$ for cosmic radiation (Prescott and Hutton, 1994) and the correction $\mathrm{k}=0.1$ (for small effectiveness of generating thermoluminescence when subjected to $\alpha$ radiation) are taken (cf. Benea et al., 2007). For the samples of pottery from the Nieszawa Kolonia and Kręcieszki sites the dose rate DR (Table 1) was calculated as a sum of components coming from $\alpha$ and $\beta$ radiation emitted by nuclides occurring in pottery sample and absorbed by mineral grains of this sample, $\gamma$ radiation emitted by isotopes occurring in deposit but absorbed by mineral grains of pottery sample, and cosmic 


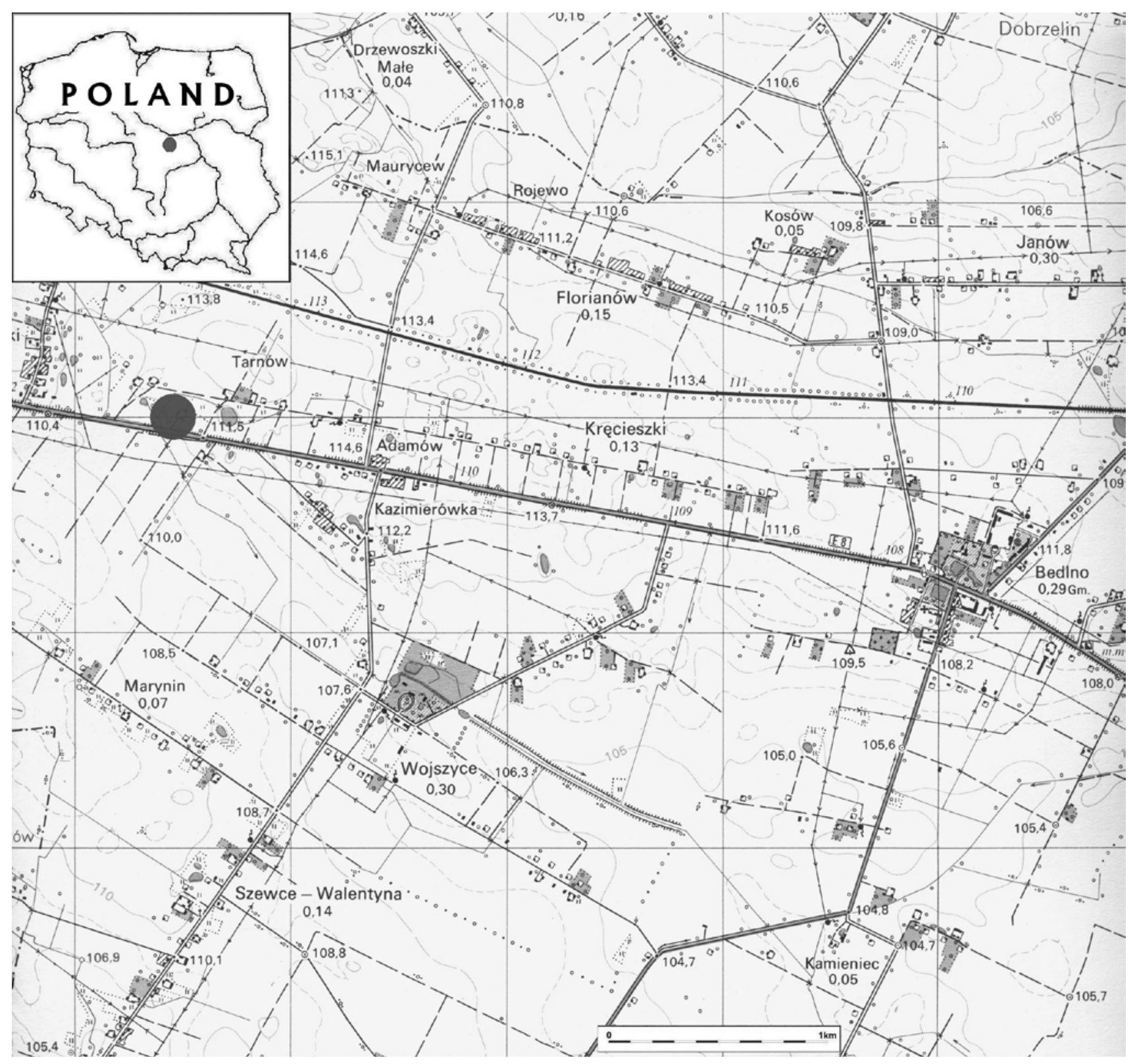

Fig. 3. Location of the Kręcieszki site

radiation (Bluszcz and Adamiec, 1994; Bluszcz and Pazdur, 1994).

The measurements of radioisotopes were carried out in the laboratory using a three-channel, stationary gamma spectrometer type MAZAR-95 produced by POLONIZOT (Poland) with scintillation probe with NaJ/Tl crystal. The deposit portions of about $600 \mathrm{~g}$ in weight in the Marinelli-type containers were put in a lead housing with $5 \mathrm{~cm}$ thick walls. The pottery or clay daub plates (not crushed) of $60-100 \mathrm{~g}$ in weight and about $60 \mathrm{~mm}$ in diameter were put in a specially designed lead chamber with $10 \mathrm{~cm}$ thick walls. The measurement time was about 70 hours ( 3 cycles of 80000 seconds each) for deposit and about 200 hours ( 3 cycles of 240000 seconds each) for pottery or clay daub sample. So long time was used in order to diminish the measurement uncertainty, and the differences in the measurement time between deposit and artefact resulted from their volume.

The DR was calculated with the correction for sample moisture of about $15 \%$. Natural moisture of artefact and deposit was measured in laboratory before TL age determination. Pottery and samples of deposits were put in plastic bags in order to protect them from loss of moisture. Seasonal and long-term changes of moisture were taken into consideration basing on the data collected during geological survey carried out in the Lublin Upland for the Detailed Geological Map of Poland 1:50000 (Rzechowski, 1995). 
In order to determine archaeological dose a pottery or clay daub sample of about $10 \mathrm{~g}$ in weight was taken and its $2-3 \mathrm{~mm}$ thick external layer was removed. Then a sample was carefully crushed and the $30-40 \mu \mathrm{m}$ polymineral fraction was separated using sieve method. The obtained mineral material was cleaned by etching with acetic acid (1:1) for 30 minutes (Martini et al., 2001). Feldspars constitute only several per cent (determined by staining of feldspar) of this fraction so separation of minerals was not made. The mineral material was divided into two parts. The first one was divided into several portions. One was left as natural, and the remaining por- tions were irradiated with the ionising radiation doses of $2.5 \mathrm{~Gy}, 5 \mathrm{~Gy}, 7.5 \mathrm{~Gy}$ and $10 \mathrm{~Gy}$. Then the mineral material was divided into the portions of $4 \mathrm{mg}$ in weight, which were placed in the TL reader/analyser RA'94 type (with the EMI 9789 QA photomultiplier) produced by Mikrolab Kraków (Poland). Aliquots are glowed out in argon atmosphere at a heating rate of $10^{\circ} \mathrm{C} / \mathrm{s}$ up $400^{\circ} \mathrm{C}$. Based on the obtained glow curves (relationship between thermoluminescence and temperature, Fig. 4), the equivalent dose (ED) was determined by additive method (Fig. 5A). In order to determine the correction (I) due to the fact of non-linear relation $T L=f(D)$ for small absorbed

Table 1. The values of dose rate $(D R)$, archaeological dose $(A D)$ and $T L$ age of pottery and clay daub.

\begin{tabular}{|c|c|c|c|c|c|c|c|}
\hline $\begin{array}{c}\text { Lab. No. } \\
\text { of sample } \\
\text { Lub- }\end{array}$ & $\begin{array}{l}\text { Inden- } \\
\text { tory No. }\end{array}$ & $\begin{array}{c}\mathrm{K} \\
(\mathrm{Bq} / \mathrm{kg})\end{array}$ & $\begin{array}{c}\mathrm{U} \\
(\mathrm{Bq} / \mathrm{kg})\end{array}$ & $\begin{array}{c}\text { Th } \\
(\mathrm{Bq} / \mathrm{kg})\end{array}$ & $\begin{array}{l}\text { Dose rate } \\
\text { DR (Gy/ka) }\end{array}$ & $\begin{array}{c}\text { Archaeol- } \\
\text { ogical dose AD } \\
\text { (Gy) }\end{array}$ & $\begin{array}{l}\text { TL age } \\
\text { (a) }\end{array}$ \\
\hline \multicolumn{8}{|c|}{ Nieszawa Kolonia site } \\
\hline 4603 & 4699 & $369.7 \pm 11.1$ & $27.1 \pm 1.9$ & $40.0 \pm 2.2$ & $3.86 \pm 0.13$ & $6.2 \pm 0.4$ & $1610 \pm 120$ \\
\hline 4604 & 4727 & $375.5 \pm 11.3$ & $23.9 \pm 1.7$ & $40.9 \pm 2.4$ & $3.62 \pm 0.17$ & $6.4 \pm 0.4$ & $1740 \pm 130$ \\
\hline 4605 & 4177 & $438.7 \pm 13.2$ & $22.9 \pm 1.6$ & $37.5 \pm 2.1$ & $4.27 \pm 0.11$ & $3.4 \pm 0.2$ & $796 \pm 60$ \\
\hline 4606 & 4679 & $462.6 \pm 13.9$ & $36.1 \pm 2.5$ & $51.5 \pm 2.8$ & $4.94 \pm 0.16$ & $4.5 \pm 0.3$ & $910 \pm 70$ \\
\hline 4607 & 3176 & $425.0 \pm 12.8$ & $20.5 \pm 1.4$ & $33.6 \pm 1.8$ & $4.04 \pm 0.14$ & $6.0 \pm 0.4$ & $1490 \pm 110$ \\
\hline 4608 & 3160 & $412.9 \pm 12.4$ & $13.6 \pm 0.9$ & $41.6 \pm 2.3$ & $4.02 \pm 0.11$ & $6.1 \pm 0.4$ & $1520 \pm 120$ \\
\hline 4609 & 4723 & $369.5 \pm 11.5$ & $16.6 \pm 1.2$ & $36.8 \pm 2.0$ & $3.52 \pm 0.12$ & $5.9 \pm 0.4$ & $1680 \pm 130$ \\
\hline 4610 & 2555 & $383.0 \pm 11.5$ & $22.2 \pm 1.6$ & $26.5 \pm 1.5$ & $3.51 \pm 0.11$ & $8.0 \pm 0.6$ & $2250 \pm 170$ \\
\hline 4611 & 4741 & $367.0 \pm 11.0$ & $26.8 \pm 1.9$ & $41.9 \pm 2.3$ & $3.62 \pm 0.12$ & $6.2 \pm 0.4$ & $1710 \pm 130$ \\
\hline 4612 & 4434 & $370.0 \pm 10.9$ & $21.6 \pm 1.5$ & $39.5 \pm 2.2$ & $3.48 \pm 0.13$ & $6.5 \pm 0.5$ & $1870 \pm 140$ \\
\hline 4613 & 4613 & $296.8 \pm 8.9$ & $15.3 \pm 1.1$ & $39.7 \pm 2.3$ & $2.74 \pm 0.12$ & $4.4 \pm 0.3$ & $1610 \pm 150$ \\
\hline deposit & ----- & $160.5 \pm 4.8$ & $5.2 \pm 0.4$ & $1.4 \pm 0.1$ & $0.71 \pm 0.03$ & 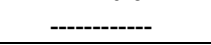 & -------- \\
\hline \multicolumn{8}{|c|}{ Kręcieszki site } \\
\hline 4387 & $\begin{array}{c}\text { clay daub } \\
\text { vessel }\end{array}$ & $380.0 \pm 11.4$ & $22.3 \pm 1.6$ & $25.7 \pm 1.4$ & $2.71 \pm 0.14$ & $4.8 \pm 0.2$ & $1780 \pm 130$ \\
\hline $\begin{array}{c}4388 \\
\text { deposit }\end{array}$ & ----- & $\begin{array}{c}471.8 \pm 14.2 \\
95.7 \pm 2.9\end{array}$ & $\begin{array}{c}43.4 \pm 3.0 \\
6.3 \pm 0.4\end{array}$ & $\begin{array}{c}23.5 \pm 1.3 \\
3.1 \pm 0.2\end{array}$ & $\begin{array}{l}4.99 \pm 0.23 \\
0.57 \pm 0.03\end{array}$ & 8.5 & $1710 \pm 120$ \\
\hline
\end{tabular}

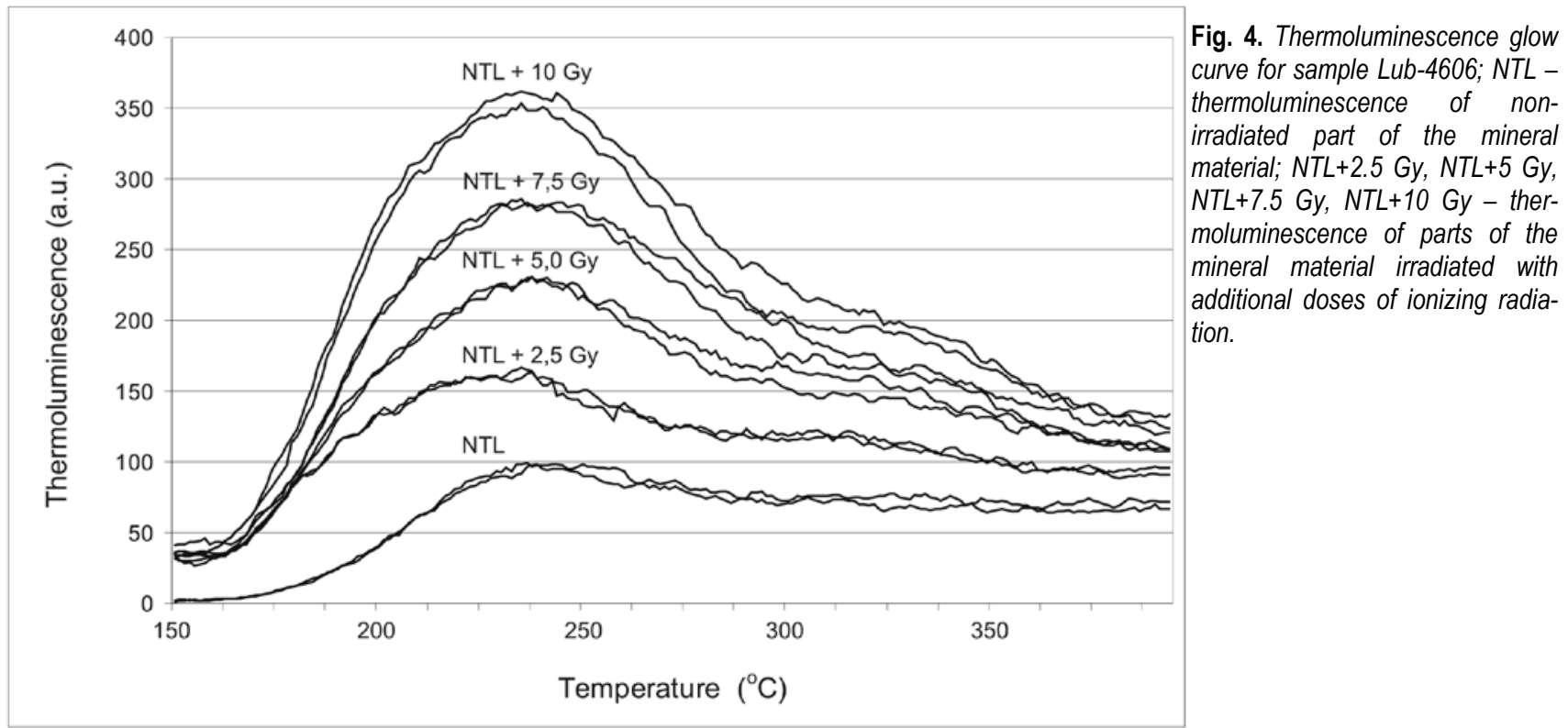


doses, the second part of mineral material was heated at $500^{\circ} \mathrm{C}$ for 3 hours. Then it was divided into portions and irradiated with the same doses as those used for ED determination (Fig. 5B). During thermoluminescence measurements an optical filter HA-3 was used to cut infra red radiation of heater. The values of dose rate (DR), archaeological dose (AD) and TL age are listed in Table 1. The TL light sum was read under narrow region of the TL glow curve, which includes its maximum (e.g. $235-245^{\circ} \mathrm{C}$ for the sample Lub-4606; Fig. 4). Confidence interval of the obtained values of TL age is $68 \%$.

\section{CRITERIA OF MATERIAL SELECTION FOR TL DATING}

All units selected for TL dating are connected with the Przeworsk Culture. Their ages, determined using archaeological methods, fall within the above-mentioned settlement stages. There were selected the features of different function such as storage pits, dwelling buildings, hearths, post holes.

Among the selected features from the Nieszawa Kolonia site, besides pottery, other non-ceramic dating artefacts were found in seven of them $(51,59,63,99,113$ and $113 \mathrm{t}, 116)$. They enable us to assign the structures to the first or second stage of settlement functioning. Two pits containing only pottery material can be also related to the second stage because the fragments of wheel-made vessels (No. 122) and Krausengefässe storage vessels (No. 87) were found in their fillings. In two features
(116A and 117), from which pottery samples were taken for TL analysis, dating artefacts were absent. Therefore, they were generally related to the Roman period and early stage of the Migration period (Table 3).

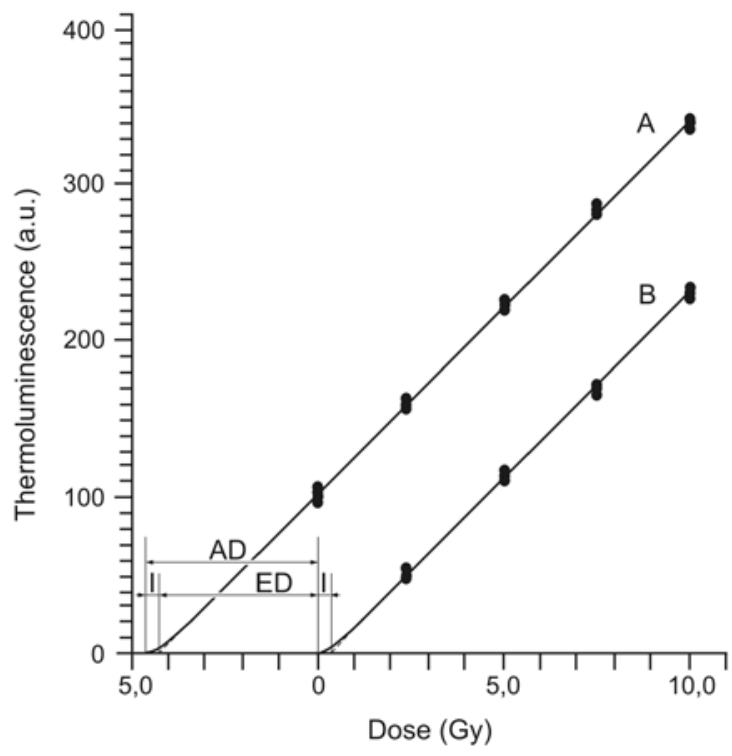

Fig. 5. Thermoluminescence growth curves for sample Lub-4606. Calculation: archaeological dose $(A D)$ as sum of equivalent dose (ED) and correction for supralinearity (I).

Table 2. Nieszawa Kolonia, site No. 5. List of pottery and clay daub fragments selected for analysis.

\begin{tabular}{|c|c|c|c|c|c|}
\hline $\begin{array}{l}\text { Lab. No. } \\
\text { of sample }\end{array}$ & $\begin{array}{l}\text { Inventory } \\
\text { No. }\end{array}$ & Excava-tion & Object & Object function & Description of pottery fragments selected for analysis \\
\hline Lub-4603 & 4699 & 10 & 117 & hearth & fragment of belly of thick-walled vessel of I3 group ${ }^{[1]}$ \\
\hline Lub-4604 & 4727 & 10 & 122 & hearth & rim part of wheel-made vase-like vessel of I group ${ }^{[1]}$ \\
\hline Lub-4605 & 4177 & 8 & 87 & storage pit & $\begin{array}{l}\text { fragment of belly of storage vessel, so-called Krausen-gefässe, wheel- } \\
\text { made, Illa }\end{array}$ \\
\hline Lub-4606 & 4679 & 10 & 116 & hearth & fragment of belly of thick-walled vessel of I3 group \\
\hline Lub-4607 & 3176 & 5 & 59 & $\begin{array}{l}\text { dwelling feature of post } \\
\text { construction }\end{array}$ & fragment of belly of thick-walled vessel of I3-14 group \\
\hline Lub-4608 & 3160 & 5 & 63 & storage pit & fragment of belly of thick-walled storage vessel of I2-I3 group \\
\hline Lub-4609 & 4723 & 10 & $116 \mathrm{~A}$ & storage pit & base part of small average-walled vessel of 12 group \\
\hline Lub-4610 & 2555 & 4 & 51 & $\begin{array}{l}\text { dwelling feature of post } \\
\text { construction }\end{array}$ & rim part of thin-walled vase-like vessel of II2 group \\
\hline Lub-4611 & 4741 & 10 & 113 & $\begin{array}{l}\text { farm building (?) of post } \\
\text { construction }\end{array}$ & fragment of belly of thick-walled storage (?) vessel of I3 group \\
\hline Lub-4612 & 4434 & 9 & 99 & hearth & fragment of belly of thick-walled vessel of I3 group \\
\hline Lub-4613 & 4613 & 10 & 113, „t" & post hole & fragment of clay daub with imprints of wood from building construction \\
\hline
\end{tabular}

${ }^{1}$ Symbols denoting technological groups and subgroups are adopted from the study of hand-made pottery of the Przeworsk Culture from the Lublin region, based on the material from the burial ground in Opoka, Puławy county. These are the following groups: pottery with blackened surface /// and brown pottery /II/, and within them: polished /1/, burnished /2/, coarse /3/, roughened /4/, coarse, in places burnished /2-3/, coarse, in places roughened /3-4/ (M. Stasiak 1994, p. 43-45). The mentioned paper contains the detailed description of the technological features of these units.

${ }^{2}$ Wheel-made vessels of the Przeworsk Culture are described according to the technological classification of the materials from Igołomia, Cracow county. These are the following groups: pottery with coarse surface, so-called kitchen /I/, pottery with burnished surface, so-called table /II/, storage vessels of coarse surface /III/ (H. Dobrzańska 1990, p. 16-20). The mentioned paper contains the further detailed description of the technological features of these units. 
Table 3. Nieszawa Kolonia, site No. 5. List of the results of TL dating of pottery and clay daub.

\begin{tabular}{|c|c|c|c|c|}
\hline $\begin{array}{l}\text { Lab. No. } \\
\text { of sample }\end{array}$ & $\begin{array}{l}\text { Inventory } \\
\text { No. }\end{array}$ & $\begin{array}{l}\text { Relative chronology of objects } \\
\text { (AD) }\end{array}$ & $\begin{array}{c}\text { TL age } \\
\text { (BP) }\end{array}$ & $\begin{array}{l}\text { TL age } \\
\text { (AD) }\end{array}$ \\
\hline Lub-4603 & 4699 & $\begin{array}{l}\text { OR- OWL1 } \\
\text { (about } 0 \text { AD - about } 450 A D \text { ) }\end{array}$ & $1606 \pm 122$ & $402 \pm 122$ \\
\hline Lub-4604 & 4727 & $\begin{array}{l}\text { phases C2 - D } \\
\text { (about } 260 \text { AD - about } 450 \mathrm{AD} \text { ) }\end{array}$ & $1740 \pm 132$ & $268 \pm 132$ \\
\hline Lub-4605 & 4177 & $\begin{array}{l}\text { phases } C 2 \text { - D } \\
\text { (about } 260 \mathrm{AD} \text { - about } 450 \mathrm{AD} \text { ) }\end{array}$ & $796 \pm 60$ & $1212 \pm 60$ \\
\hline Lub-4606 & 4679 & $\begin{array}{l}\text { phases B2/C1 - C1a } \\
\text { (about } 150 A D \text { - about 210-230 AD) }\end{array}$ & $911 \pm 69$ & $1097 \pm 69$ \\
\hline Lub-4607 & 3176 & $\begin{array}{l}\text { phases B2/C1 - C1a } \\
\text { (about } 150 \text { AD - about 210-230 AD) }\end{array}$ & $1485 \pm 113$ & $523 \pm 113$ \\
\hline Lub-4608 & 3160 & $\begin{array}{l}\text { phases C3 - D } \\
\text { (about } 310 \text { r. - about } 450 \text { AD) }\end{array}$ & $1517 \pm 115$ & $491 \pm 115$ \\
\hline Lub-4609 & 4723 & $\begin{array}{l}\text { OR - OWL } \\
\text { (about } 0 A D \text { - about } 450 A D \text { ) }\end{array}$ & $1676 \pm 127$ & $332 \pm 127$ \\
\hline Lub-4610 & 2555 & $\begin{array}{l}\text { phases B2/C1 - C1a } \\
\text { (about } 150 \text { AD - about 210-230 AD) }\end{array}$ & $2251 \pm 171$ & $243 \pm 171 \mathrm{BC}$ \\
\hline Lub-4611 & 4741 & $\begin{array}{l}\text { phases } C 2 \text { - D } \\
\text { (about } 260 A D \text { - about } 450 A D \text { ) }\end{array}$ & $1713 \pm 130$ & $295 \pm 130$ \\
\hline Lub-4612 & 4434 & $\begin{array}{l}\text { phase } B 2 \\
\text { (about } 80 \mathrm{AD} \text { - about } 150 \mathrm{AD} \text { ) }\end{array}$ & $1868 \pm 142$ & $140 \pm 142$ \\
\hline Lub-4613 & 4613 & $\begin{array}{l}\text { phases } C 2 \text { - D } \\
\text { (about } 260 A D \text { - about } 450 A D \text { ) }\end{array}$ & $1606 \pm 145$ & $402 \pm 145$ \\
\hline
\end{tabular}

${ }^{1} \mathrm{OR}$ - Roman period (period of Roman influence), OWL - Migration period

The pottery samples were selected taking into account also their representative character in respect of their technological and morphological features typical of the vessels of the Przeworsk Culture from the Roman period. The detailed description of the pottery fragments selected for analysis is presented in Table 2. For the groups and types of hand-made pottery it is based on the materials from the burial ground in Opoka, Puławy county (Stasiak, 1994) and for wheel-made pottery - on the classification of vessels from Igołomia, Cracow county (Dobrzańska, 1990).

In the Kręcieszki site, besides pottery, dating artefacts were absent. Moreover, pottery is not very typical. In order to check the TL age obtained for pottery, we decided to make an attempt at TL dating of other materials. Therefore, for the first time in the Lublin laboratory, a fragment of burnt clay daub was TL dated (Kusiak et al., 2009). TL dating of burnt house daub (12 samples from Birini Site in Northern Ghana) was described by Godfrey-Smith et al. (1997). The obtained results correspond well to the radiocarbon ages suggesting that reliable TL dating results can be obtained for burnt house daub.

\section{RESULTS AND DISCUSSION}

In case of the Nieszawa Kolonia site, eight of eleven obtained TL results are within the time-frame of the Roman and Migration periods, i.e. between the $1^{\text {st }}$ and $5^{\text {th }}$ century AD (Table 3 ). Five of these TL ages, obtained for clay daub and pottery, well correspond to the stages of settlement functioning determined from dating artefacts. One TL dating result is incompatible with the detailed relative chronology within the Roman and Migration periods. (Table 3, inventory No. 3176). Two TL ages obtained for pottery fragments generally dated to the Roman and Migration periods (Table 3, inventory No. 4723 and 4699) could be also regarded as positive results.

We can hazard a guess that the TL dating of pottery and clay daub from the Nieszawa Kolonia site confirms two stages of settlement. One TL age (140 \pm 142 AD) corresponds to the first stage of settlement functioning, i.e. the phase B2b of the Roman period. As many as six TL ages, ranging from $268 \pm 132$ to $491 \pm 115 \mathrm{AD}$, correspond to the phases C2 - D, i.e. to the second stage of settlement, from the second half of the $3^{\text {rd }}$ century to the half of the $5^{\text {th }}$ century AD.

Three dates obtained by the TL method are completely incompatible with the accepted chronology of the features from which the samples were collected. Two TL results indicate the early Middle Ages (Table 3, inventory No. 4679 and 4177 ) and one - the early pre-Roman period (Table 3, inventory No. 2555). It should be stressed that faulty dating of these samples using archaeological methods is very little probable. The selected samples are fragments of typical (in respect of technology and form) vessels from the Roman period. The incompatibility of the TL date with the result of archaeological dating is especially disappointing in case of the sample of inventory No. 4177 from the pit 87 as it is the fragment of belly of thick-walled storage vessel with everted rim, 
so-called Krausengefässe, dated to the phase C2-D of the Roman period (Stasiak-Cyran, 2008).

In the Kręcieszki site the results of TL dating of pottery and clay daub are rather similar and correspond to the phase $\mathrm{B} 1 / \mathrm{B} 2$ of the period of Roman influence, determined from pottery style, but can also indicate the phase B2/C1 (Table 1). The TL dating of burnt clay daub was successful. It turned out that clay daub is equally good dating material as pottery.

\section{FINAL REMARKS AND CONCLUSIONS}

In should be stated that thermoluminescence dating of artefacts from the Nieszawa Kolonia and Kręcieszki sites was successful.

The main value of the TL analysis carried out for the Nieszawa Kolonia site is the fact that quite many fragments of pottery were dated. The results confirm the chronology deduced from relative dating materials, and the obtained TL ages indicate age brackets of two settlement stages. However, we do not find any chronological order of the TL ages of pottery representing different technological groups and styles. Many more TL dating results should be obtained to observe possible relations between the occurrence of pottery representing different technological groups and styles and particular phases of the second settlement stage.

It is also important that TL dating enables us to determine the chronology of features without good relative dating materials. Such a situation occurred both in the Nieszawa Kolonia and Kręcieszki sites.

It is advisable to carry out TL dating of at least several fragments of pottery collected in one site in order to minimize the possibility of false determination of the site age. Interpretation of single results can lead to wrong conclusions. Such a situation we have in the Nieszawa Kolonia site. Single fragments of pottery, the TL age of which was incompatible with the expected age, occurred also in almost all series of samples from several sites dated in the Lublin laboratory. Many TL dating results obtained for one feature give the possibility to separate accidental results from those well dating the examined structure. In this stage of the investigations we cannot identify the causes of this incompatibility. The causes of the above mentioned incompatibility are an important problem to solve.

Pottery is commonly used in the TL dating of archaeological features (Preusser et al., 2008; Wintle, 2008). However, burnt clay daub is also good dating material, as it was evidenced by the obtained TL ages.

The obtained results enable us to make good predictions for future TL dating of archaeological fired materials.

\section{ACKNOWLEDGEMENT}

We would like to express our gratitude to Dr. Maria Wilgat who prepared the English version of this paper. The project was financed by the Ministry of Culture and National Heritage and The Lublin Province Museum.

\section{REFERENCES}

Abramek B, 1993. Grupa osad kultury przeworskiej z nad południowego odcinka Warty datowanych od III-II w. p.n.e. do V-VI w. n.e. (Group of settlements of the Przeworsk Culture on the Warta River southern section, dated from 300-200 BC to 500-600 AD). Sieradzki Rocznik Muzealny 9: 49-68 (in Polish).

Adamiec G and Aitken MJ, 1998. Dose-rate conversion factors: update. Ancient TL 16(2): 37-50.

Barłowska A, 1984. Osada z późnego okresu rzymskiego w Lesku, woj. Krosno. (The settlement from the late Roman period in Lesko, Krosno province). MSROA 1976-1979: 51-101 (in Polish).

Benea V, Vandenberghe D, Timar A, Van den Haute P, Cosma C, Gligor M and Florescu C, 2007. Luminescence dating of Neolithic ceramics from Lumea Noua, Romania. Geochronometria 28: 9-16, DOI 10.2478/v10003-007-0027-9.

Bluszcz A and Adamiec G, 1994. Termoluminescencyjne datowanie neolitycznej ceramiki z terenu Małopolski (okolice Kazimierzy Wielkiej) (Thermoluminescence dating of the Neolithic pottery from the Małopolska region (the environs of Kazimierza Wielka)). Światowit 39: 157-181 (in Polish).

Bluszcz A and Pazdur MF, 1994. Porównanie typologiczne datowania ceramiki z wynikami fizycznych metod datowania (Comparison of the typological dating of ceramics with the results of physical dating methods). Światowit 39: 182-192 (in Polish).

Dobrzańska H, 1990. Osada z późnego okresu rzymskiego w Igołomii, woj. krakowskie (The settlement from the late Roman period in Igołomia, Cracow province). Część I i II, Wrocław-WarszawaKraków-Gdańsk-Łódź (in Polish).

Godfrey-Smith DI, Casey JL and Sawatzky RM, 1997. First evidence for multiple phases of the Kintampo Complex: thermoluminescence chronology of burnt house daub at Birimi, Ghana. Abstracts, GSA Annual Meeting, Salt Lake City, Oct. 20-23, 1997.

Godłowski K, 1981. Kultura przeworska (Przeworsk Culture). PZPol. 5: 57-135 (in Polish)

Kipfer BA, 2007. Dictionary of artifacts. Blackwell Publishing: 346pp.

Kokowski A, 1988. Ze studiów nad ceramiką wykonaną na kole w kulturze wielbarskiej (About the research on wheel-made pottery of the Wielbark Culture). Kultura wielbarska 1: 157-176 (in Polish).

Kokowski A, 1989. Wielokulturowe stanowisko 2 w Drążgowie, gm. Ułęż, woj. Lubelskie (Multicultural site No 2 in Drążgów, Ułęż district, Lublin province). Sprawozdania UMCS: 29-32 (in Polish).

Kokowski A, 1991. Lubelszczyzna $w$ młodszym okresie przedrzymskim $i$ $w$ okresie rzymskim (Lublin region in the younger pre-Roman and Roman periods). Lublin: 235 pp (in Polish).

Kondracki J, 1994. Geografia Polski, mezoregiony fizycznogeograficzne (Geography of Poland, physical-geographical mesoregions). Wydawnictwo Naukowe PWN: 340pp (in Polish).

Kusiak J, Łanczont M, Dzieńkowski T and Rychter M, 2009. Nowe możliwości zastosowania metody datowania termoluminescencyjnego w badaniach archeologicznych (New possibilities of using of thermoluminescence dating in archaeological investigations). In: Fudziński M and Paner H, eds., Aktualne problemy epoki kamienia na Pomorzu. Muzeum Archeologiczne w Gdańsku: 165-170 (in Polish).

Martini M, Sibilia E, Croci S, and Cremachi M, 2001. Thermoluminescence (TL) dating of burnt flint: problems, perspectives and some 
examples of application. Journal of Cultural Heritage 2(3): 179190, DOI 10.1016/S1296-2074(01)01126-8.

Mączyńska M, 1999. Schyłkowa faza kultury przeworskiej (Final phase of the Przeworsk Culture). Kultura Przeworska 4: 25-54 (in Polish).

Mejdahl V and Wintle AG, 1984. Thermoluminescence applied to age determination in archa-eology and geology. In: Horowitz YS, ed., Thermoluminescence and thermoluminescent dosimetry, Boca Raton, CRC Press, v. III: 133-190.

Michałowski A, 2003. Osady kultury przeworskiej z terenu ziem polskich (The Przeworsk Culture settlements in Poland). Poznan: 251pp (in Polish).

Prescott JR and Hutton JT, 1994. Cosmic ray contributions to dose rates for luminescence and ESR dating: large depths and long-term time variations. Radiation Measurements 23(2-3): 497-500, DOI 10.1016/1350-4487(94)90086-8.

Preusser F, Degering D, Fuchs M, Hilgers A, Kadereit A, Klasen N, Krbetschek M, Richter D and Spencer JQG, 2008. Luminescence dating: basics, methods and applications. Eiszeitalter und Gegenwart Quaternary Science Journal 57(1-2): 95-149, DOI 10.3285/eg.57.1-2.5.

Rychter M, 2010. Elementy konstrukcyjne domu „ryglowego” z okresu wpływów rzymskich odkrytego na stanowisku $\mathrm{nr}$ 1w Kręcieszkach (Structural elements "bolt" home from the Roman period discovered at the site No. 1 in Kręcieszki). Monumenta Archaeologica Barbaria, series Gemina 2: 745-755 (in Polish).

Rychter M and Stasiak S, 2006. Cmentarzysko ludności kultury pomorskiej w Kręcieszkach gm. Bedlno, pow. Kutno, woj. Łódzkie (Graveyard of the population in the Pomeranian culture in Kręcieszki site). Eódzkie Sprawozdania Archeologiczne 10: 27-70 (in Polish).

Rzechowski J, 1995. Wskaźniki wilgotności osadów mineralnych z obszaru Polski SE (Indi-cators of moisture of mineral deposits from SE Poland). Maszynopis opracowania przechowywany $w$ laboratorium TL w Instytucie Nauk o Ziemi UMCS (Manuscript studies stored in the TL laboratory at the Institute of Earth Sciences, UMCS). Warszawa: 20pp (in Polish).

Stasiak M, 1994. Ceramika z cmentarzyska kultury przeworskiej w Opoce (Pottery from the Przeworsk Culture burial ground in Opoka). Kultura przeworska 2: 45-63 (in Polish).

Stasiak-Cyran M, 2000. Wyniki piątego sezonu badań na osadzie kultury przeworskiej w Nieszawie Kolonii, stanowisko 5, pow. Opole Lubelskie (The results of the fifth field season of investigations of the Przeworsk Culture settlement in Nieszawa Kolonia, site No 5 , Opole Lubelskie county). Archeologia Polski Środkowowschodniej V: 84-95 (in Polish).

Stasiak-Cyran M, 2005. Wyniki badań ratowniczych na terenie osady kultury przeworskiej w Nieszawie Kolonii, stanowisko 5, pow. Opole Lubelskie, w 2003 roku (The results of rescue investigations in the area of the Przeworsk Culture settlement in Nieszawa Kolonia, site No 5, Opole Lubelskie county, in 2003). Archeologia Polski Środkowowschodniej VII: 95-101 (in Polish).

Stasiak-Cyran M, 2008. A settlement in Nieszawa Kolonia and the problem of the end of the Przeworsk Culture in the western Lublin region. In: Niezabitowska-Wiśniewska B, Juściński M, Łuczkiewicz $\mathrm{P}$ and Sadowski S, eds., The turbulent epoch. New materials from the Late Roman Period and the Migration Period, Lublin: 309-328.

Szydłowski J, 1964. Cmentarzysko z okresu wpływów rzymskich w Choruli, powiat Krapko-wice (Burial ground from the period of Roman influence in Chorula, Krapkowice county). Wrocław: $164 p p$ (in Polish).

Wintle AG, 2008. Fifty years of luminescence dating. Archaeometry 50(2): 276-312, DOI 10.1111/j.1475-4754.2008.00392.x. 